GRASAS Y ACEITES 66 (4)

October-December 2015, e099

ISSN-L: 0017-3495

doi: http://dx.doi.org/10.3989/gya.0228151

\title{
Labeled extra virgin olive oil as food supplement; phenolic compounds in oils from some autochthonous Croatian olives
}

\author{
C. Jakobušić Brala ${ }^{\mathrm{a}, \bowtie}$, Đ. Benčić ${ }^{\mathrm{b}} \bowtie$, Z. Šindrak ${ }^{\mathrm{b}}$, M. Barbarića and S. Uršića \\ ${ }^{a}$ Faculty of Pharmacy and Biochemistry, University of Zagreb, A. Kovačića 1, 10000 Zagreb, Croatia \\ ${ }^{b}$ Faculty of Agriculture, University of Zagreb, Svetošimunska 25, 10000 Zagreb, Croatia \\ ${ }^{\square}$ Corresponding author: cjakobus@pharma.hr, bencic@agr.hr
}

Submitted: 02 February 2015; Accepted: 18 May 2015

\begin{abstract}
SUMMARY: Within the framework of an incentive to provide labeled extra virgin olive oils as a food supplement in pharmacies, the phenolic profile analysis of extra virgin olive oils obtained from Croatian olive cultivars has been reported. With the aim of increasing the consumption of EVOO-s in northern Croatia, the varieties Bjelica, Buža and Italian Leccino have been studied involving two different agroclimatic locations, over two harvest years differing significantly in the amount of rainfall. The Croatian cultivars Plominka, Žižolera, Oblica and Lastovka, were also examined. Correlation tests and the insight from PCA reveal that the cultivars are highly individualized in character with regard to relationships among phenolic compounds. Some elements of an innovative labeling aimed to better present the authenticity, quality, excellence and uniqueness of the EVOO-s were suggested.
\end{abstract}

KEYWORDS: Autochthonous Croatian olive varieties; Extra virgin olive oil; Labeling; Phenolic compounds

RESUMEN: Aceites de oliva virgen extra etiquetados como suplemento alimenticio; compuestos fenólicos en aceites de aceitunas autóctonas croatas. En el marco de los incentivos que se han considerado para proporcionar el etiquetado de aceites de oliva virgen extra como suplemento alimenticio en farmacias, se reporta el análisis del perfil fenólico de aceites de oliva vírgenes extra obtenidos a partir de variedades croatas. Para ampliar el consumo de AOVE-s en el norte de Croacia, se han estudiado las variedades Bjelica, Buža y Leccino italiana procedentes de dos lugares agroclimáticos diferentes que difieren significativamente en la cantidad de lluvia y obtenidos en dos cosechas. Tambien fueron examinados los cultivares croatas Plominka, Žižolera, Oblica y Lastovka. Los test de correlación y los resultados de PCA revelan que las variedades están altamente individualizados en su carácter en lo que respecta a las relaciones entre los compuestos fenólicos. Se sugirieron algunos elementos innovadores para un etiquetado dirigido a presentar mejor la autenticidad, la calidad, la excelencia y la singularidad de los AOVE-s.

PALABRAS CLAVE: Aceite de oliva virgen extra; Compuestos fenólicos; Etiquetado; Variedades de aceitunas autóctonas croatas

Citation/Cómo citar este artículo: Jakobušić Brala C, Benčić Đ, Šindrak Z, Barbarić M and Uršić S. 2015. Labeled extra virgin olive oil as food supplement; phenolic compounds in oils from some autochthonous Croatian olives. Grasas Aceites 66 (4): e099. doi: http://dx.doi.org/10.3989/gya.0228251.

Copyright: (C) 2015 CSIC. This is an open-access article distributed under the terms of the Creative Commons Attribution-Non Commercial (by-nc) Spain 3.0 Licence. 


\section{INTRODUCTION}

The evidence suggesting many beneficial health effects associated with the dietary consumption of extra virgin olive oils (EVOO-s) has steadily accumulated for decades. More recent studies and reviews, for example, by Oliveras-Lopez et al. (2014), Garcia-Martinez et al. (2014a, 2014b), Estruch et al. (2013), Sofi et al. (2010) and Fung et al. (2009) fit the same general picture presented by Keys (1970) and Martinez-Gonzales et al. (2002) and LópezMiranda et al. (2010) or Lipworth et al. (1997). The phenolic compounds, naturally present in EVOO-s are deemed to be of central importance for these beneficial cardiovascular, according to Estruch et al. (2013), Fung et al. (2009), Valls et al. (2015), antiatherogenic/antiinflammatory, Scoditti et al. (2014), Lu et al. (2013), Cabrerizo et al. (2013), anticancer, Hashim et al. (2008), Lamy et al. (2014), Hashim et al. (2014), antioxidant and antimicrobial effects Cicerale et al. (2012), Karaosmanoglu et al. (2010), Paiva-Martins et al. (2013), Giordano et al. (2014).

Olive cultivation and olive oil consumption are traditional in southern Croatia. In contrast to the millenary tradition on the Croatian coast and islands of the Adriatic, olive oil consumption is substantially lower in the northern continental part of Croatia. Although people in northern Croatia traditionally use sunflower oil more frequently than olive oil, a lack of enforced standards for EVOO in the consumer market also may play a role. As Clodoveo et al. (2014) noted, consumers place a high value on the accurate and defensible labeling of EVOO-s, also involving voluntary information such as the olive variety used. In order to extend the consumption of EVOO-s in northern Croatia, an incentive has been considered to provide labeled extra virgin olive oils as a food supplement in pharmacies, where a number of food supplements associated with some health effect expectations, such as blackberry wine, for example, had already been well marketed. This should involve an innovative labeling that includes, among others, the contents of essential phenolics such as hydroxytyrosol, tyrosol and oleuropein as well as total phenolics and possibly some important minor phenolics. In addition, accordinng to prevailing practices and popular traditions in the country, extra virgin olive oils from autochthonous olive cultivars are preferred. Here, the results of the analysis of the phenolic profile of the extra virgin olive oils obtained from the three autochthonous Croatian olive cultivars, Buža, Plominka and Žižolera, and the domesticated cultivar Bjelica, being a part of the above mentioned incentive, are reported for the first time. Furthermore, the determination also involves two more autochthonous cultivars i.e. Oblica and Lastovka and the Italian cultivar Leccino. The investigation includes the biomedicinally most significant simple phenolic compounds, hydroxytyrosol and tyrosol, along with nine other simple phenolics and the complex phenolic compound oleuropein in the oils from two succesive crop years and different agroclimatic areas.

\section{MATERIALS AND METHODS}

\subsection{Preparation of EVOO samples}

Fruits from the autochthonous Croatian olive cultivar Buža, the domesticated (since 1929) cultivar Bjelica and the Italian cultivar Leccino (cultivated on the Istra peninsula) were collected during two succesive olive-oil years, from two significantly different agroclimatic locations of the Istra peninsula, denoted as agroclimatic location "north", N (Sovinjak, the northeastern Istra peninsula, about $300 \mathrm{~m}$ above the sea-level and $25 \mathrm{~km}$ from the sea coast) and agroclimatic location "south", S (Pula/Barbariga and Vodnjan, the southern Istra peninsula, about $10 \mathrm{~m}$ above sea-level, close to the sea coast). Samples from the autochthonous olive cultivars Plominka from the island of Cres, Žižolera from the Istra penisula (agroclimatic location "south"), Oblica and Lastovka from the island of Hvar, obtained in the second harvest year, were also examined. The two harvest years differ significantly regarding rainfall: the first year was extremely rainy and the second one suffered extreme drought. The fruits were hand-picked. Ordinarily, about $8-14 \mathrm{~kg}$ were taken from one olive tree. Olive trees were chosen randomly, though of similar age and with other apparent characteristics of olive trees. The samples from the same trees were taken in the successive olive-oil years for the sake of comparison. Only healthy fruits were processed within 24 hours after harvesting. The oil was obtained using a small extracting system (Olio mio-baby, Enologia Mori, Tuscany, Italy). Crushing, malaxation, mixing (30 min.) and the centrifuge separation was performed at a temperature no higher than $27-30^{\circ} \mathrm{C}$, using very small quantities of cold water or no water in the processing. The olive oil samples were stored in the dark in glass bottles.

\subsection{Extraction of phenolic compounds}

Phenolic compounds were extracted from the oil samples by methanol, according to the procedure of Owen et al. (2000). $20 \mathrm{~g}$ of EVOO were mixed with $4 \mathrm{~mL}$ of methanol for 30 min using a magnetic stirrer. The methanolic layer was separated by centrifugation, $30 \mathrm{~min}$ at $5000 \mathrm{rot} \cdot \mathrm{min}^{-1}$. This procedure was repeated twice. The extracts were evaporated under reduced pressure and in a nitrogen atmosphere at $32{ }^{\circ} \mathrm{C}$. The residues were suspended in acetonitrile $(5 \mathrm{~mL})$, and lipid substances were removed by shaking the suspension with hexane $(10 \mathrm{~mL})$. Acetonitrile was evaporated using a stream of nitrogen. The residues for HPLC analysis were stored at $-20^{\circ} \mathrm{C}$. 


\subsection{HPLC analysis of phenolic compounds}

The standard compounds gallic acid, tyrosol, 3,4-dihydroxybenzoic acid, $p$-hydroxybenzoic acid, homovanillyl alcohol, vanillic acid, caffeic acid, syringic acid, $p$-coumaric acid, ferulic acid and $o$-coumaric acid were obtained from Fluka, and oleuropein was from Extrasynthese (Z.I. Lion Nord, Genay). Hydroxytyrosol was prepared by the enzymatic hydroxylation of tyrosol using the mushroom tyrosinase (Espin et al., 2001).

An HPLC analysis was performed in essence by applying the procedure of Owen et al. (2000). The HPLC system, consisting of a Spectra Physics chromatograph equipped with a $250 \times 4.0 \mathrm{~mm}(5 \mu \mathrm{m}) \mathrm{C}_{18}$ Restek column was used at room temperature. Dry extracts of the samples were dissolved in $1.0 \mathrm{~mL}$ methanol and $20 \mu \mathrm{L}$ of the solution were injected into the system. The flow rate was $1 \mathrm{~mL} \cdot \mathrm{min}^{-1}$. The mobile phase used was $2 \%$ acetic acid in water (A) $v s$. methanol (B) for a total running time of $45 \mathrm{~min}$. The gradient changes were: $95 \% \mathrm{~A}-5 \% \mathrm{~B}$ for $2 \mathrm{~min}$, $75 \% \mathrm{~A}-25 \% \mathrm{~B}$ in $8 \mathrm{~min}, 60 \% \mathrm{~A}-40 \% \mathrm{~B}$ in $10 \mathrm{~min}, 50 \%$ $\mathrm{A}-50 \% \mathrm{~B}$ in $10 \mathrm{~min}$, and $0 \% \mathrm{~A}-100 \% \mathrm{~B}$ until the end of the run. The UV absorption of eluates at $278 \mathrm{~nm}$ was detected. The retention times of the standards in this system were (min): Gallic acid, 9.69; hydroxytyrosol, 12.71; 3,4-dihydroxybenzoic acid, 14.15; tyrosol, 16.82; $p$-hydroxybenzoic acid, 18.85; homovanillyl alcohol, 19.09; vanillic acid, 21.13; caffeic acid, 21.57; syringic acid, 22.55; $p$-coumaric acid, 26.73; ferulic acid, 28.20; $o$-coumaric acid, 30.66 and oleuropein, 31.25. The phenolic compounds were identified by comparing their retention times with those of the standards. The corresponding concentrations of the compounds were determined from the integrated peak areas using the appropriate calibration curves and gallic acid as the internal standard. The recovery study was also carried out according to the method of Owen et al. (2000). The extraction method used gave recoveries in the range of $75-105 \%$ of the starting values. All EVOO samples were measured at least twice to ensure reproducibility.

\subsection{Statistical analysis}

Different statistical techniques such as analysis of variance (ANOVA) using Duncan's multiple range test $(p<0.05)$, Pearson's correlation test $(p<0.01$; $p<0.05$ ) and multivariate analysis based on principal component analysis (PCA) were carried out to evaluate cultivar, crop year and location dependent differences regarding the phenolic compound composition and interrelations among them. Results are shown as the mean values and standard deviations of $n$ EVOO samples ( $n$ was at least 3, commonly 5). The statistical analysis was performed using the XLSTAT 2011 software, version 13.2.05 (Addinsoft).

\section{RESULTS AND DISCUSSION}

The selected data obtained during the investigation of the phenolic fraction of the EVOO-s from the autochthonous Croatian olive cultivars Buža, Plominka, Žižolera, Oblica and Lastovka, the domesticated (since 1929.) cultivar Bjelica and the Italian cultivar Leccino (cultivated at the Istra peninsula) are given in Tables 1 and 2. The phenolic profiles of the EVOO-s from the autochthonous cultivars Buža, Plominka, Žižolera and the domesticated cultivar Bjelica were examined for the first time. All the EVOO-s examined were obtained from conventional cultivation. In Table 1 the data obtained for the EVOO-s of Bjelica, Buža and Leccino cultivars for the two olive-oil years are presented. The data enable a comparison of the phenolic contents of the EVOO-s of Bjelica, Buža and Leccino cultivars with regard to one rainy and a succesive drought olive-oil year, also involving two significantly different agroclimatic locations. The locations (Istra peninsula) differ in their height above sea-level and their distance from the sea i.e. the southern location (Pula/ Barbariga and Vodnjan), is about $10 \mathrm{~m}$ above sealevel and close to the sea coast and the northern location (Sovinjak), is $300 \mathrm{~m}$ above sea-level and $25 \mathrm{~km}$ from the sea coast. In Table 2, the results from one crop year (corresponding to the second year denoted in Table 1) for the autochthonous cultivars Plominka, Žižolera, Oblica and Lastovka are presented.

The data presented in the Tables reveal the commonly observed difference in the contents of hydroxytyrosol and tyrosol, and other simple phenolics; whereas concentrations of hydroxytyrosol are in the range $1-12 \mathrm{mg} \cdot \mathrm{kg}^{-1}$ and tyrosol between 3 and $140 \mathrm{mg} \cdot \mathrm{kg}^{-1}$ (the latter value in the case of two samples), "minor" phenolics appeared in most cases in concentrations less than $1 \mathrm{mg} \cdot \mathrm{kg}^{-1}$ of the oil. The concentrations of hydroxytyrosol in the EVOO-s of Bjelica and Buža are in a commonly observed range, found for instance by Tura et al. (2007), Sarolić et al. (2014), Ramos-Escudero et al. (2015), Bajoub et al. (2015), and Ballus et al. (2015). Hydroxytyrosol and tyrosol in the EVOO of Leccino are present in concentrations similar to that obtained by Sarolić et al. (2014), for the same cultivar from the city of Zadar (about $200 \mathrm{~km}$ to the south-east of the Istra peninsula). The total phenolic content is effectively the same in that case (Leccino, Zadar $246 \mathrm{mg} \cdot \mathrm{kg}^{-\mathrm{l}}$ ) as for Leccino in the rainy crop year in this study $\left(254 \mathrm{mg} \cdot \mathrm{kg}^{-1}\right)$. The concentrations of the complex phenolic compound oleuropein are in the range of 1.5 and $4 \mathrm{mg} \cdot \mathrm{kg}^{-1}$ and could be similar, for example, to those reported by O. Garcia-Martinez et al. (2014a), for the Sicilian varieties Biancolilla, Passulunara, Tonda iblea etc., or Ilyasoglu et al. (2010), for the Turkish variety Ayvalik.

It could be seen that phenolic profile is characteristic of a particular olive cultivar. This can also 
TABLE 1. Phenolic compounds $\left(\mathrm{mg} \cdot \mathrm{kg}^{-1}\right)$ in virgin olive oils from three cultivars from Croatia: Bjelica, Buža, Leccino, from two agroclimatic locations in two havest years

\begin{tabular}{|c|c|c|c|c|c|c|c|}
\hline \multirow[b]{2}{*}{ Phenolic compound $\left(\mathrm{mg} \cdot \mathrm{kg}^{-1}\right)$} & \multirow[b]{2}{*}{ A.L. } & \multicolumn{3}{|c|}{$1^{\text {st }}$ year } & \multicolumn{3}{|c|}{$2^{\text {nd }}$ year } \\
\hline & & Bjelica & Buža & Leccino & Bjelica & Buža & Leccino \\
\hline \multirow[t]{2}{*}{ Hydroxytyrosol } & $\mathrm{S}$ & $2.15^{\mathrm{c}, \mathrm{d}}(1.64)$ & $3.36^{\mathrm{c}}(2.49)$ & $1.27^{\mathrm{d}, \mathrm{e}}(1.67)$ & $12.10^{\mathrm{a}}(2.26)$ & $2.48^{\mathrm{c,d}}(1.08)$ & $8.67^{\mathrm{b}}(4.71)$ \\
\hline & $\mathrm{N}$ & $0.08^{\mathrm{e}}(0.03)$ & $5.00^{\mathrm{c}, \mathrm{d}, \mathrm{e}}(6.09)$ & $0.25^{\mathrm{e}}(0.30)$ & $8.67^{\mathrm{b}}(3.88)$ & $3.58^{\mathrm{c}}(2.02)$ & $2.06^{\mathrm{cdd}}(1.43)$ \\
\hline \multirow[t]{2}{*}{ Tyrosol } & $\mathrm{S}$ & $59.49^{\mathrm{a}}(18.37)$ & $6.28^{\mathrm{f}}(1.51)$ & $13.73^{\mathrm{e}}(5.94)$ & $27.83^{\mathrm{b}}(8.67)$ & $4.70^{\mathrm{f}}(0.75)$ & $17.68^{\mathrm{d}}(6.63)$ \\
\hline & $\mathrm{N}$ & $21.77^{\mathrm{c}}(12.23)$ & $11.97^{\mathrm{e}}(7.55)$ & $10.19^{f}(10.08)$ & $11.62^{\mathrm{e}}(5.64)$ & $2.66^{\mathrm{f}}(0.59)$ & $2.85^{\mathrm{f}}(0.92)$ \\
\hline \multirow[t]{2}{*}{ 3,4dihydroxy benzoic acid } & $\mathrm{S}$ & $0.21^{\mathrm{b}}(0.11)$ & $0.16^{\mathrm{b}, \mathrm{c}}(0.01)$ & $2.17^{\mathrm{b}, \mathrm{c}}(3.12)$ & $0.03^{\mathrm{d}, \mathrm{e}}(0.00)$ & $0.03^{\mathrm{e}}(0.01)$ & $0.04^{\mathrm{c}, \mathrm{d}, \mathrm{e}}(0.02)$ \\
\hline & $\mathrm{N}$ & $0.13^{\mathrm{c}, \mathrm{d}, \mathrm{e}}(0.01)$ & $0.27^{\mathrm{a}}(0.18)$ & $0.15^{\mathrm{b}, \mathrm{c}, \mathrm{d}}(0.05)$ & $0.04^{\mathrm{c}, \mathrm{d}, \mathrm{e}}(0.03)$ & $0.07^{\mathrm{c}, \mathrm{d}, \mathrm{e}}(0.04)$ & $0.06^{\mathrm{c}, \mathrm{d}, \mathrm{e}}(0.05)$ \\
\hline \multirow[t]{2}{*}{$p$-hydroxy benzoic acid } & S & $0.43^{\mathrm{a}}(0.14)$ & $0.32^{\mathrm{b}}(0.04)$ & $0.16^{\mathrm{d}}(0.09)$ & $0.10^{\mathrm{e}}(0.07)$ & $0.25^{\mathrm{c}}(0.20)$ & $0.03^{\mathrm{f}}(0.02)$ \\
\hline & $\mathrm{N}$ & $0.21^{\mathrm{b}, \mathrm{c}, \mathrm{d}}(0.13)$ & $0.22^{\mathrm{c}}(0.03)$ & $0.23^{\mathrm{c}}(0.14)$ & $0.02^{\mathrm{f}}(0.01)$ & $0.04^{\mathrm{f}}(0.02)$ & $0.01^{\mathrm{f}}(0.01)$ \\
\hline \multirow[t]{2}{*}{ Homovanillyl alcohol } & $\mathrm{S}$ & $1.17^{\mathrm{a}}(0.49)$ & $0.32^{\mathrm{d}, \mathrm{e}, \mathrm{f}}(0.26)$ & $0.70^{\mathrm{a}, \mathrm{b}}(0.37)$ & $0.41^{\mathrm{c}, \mathrm{d}}(0.14)$ & $0.47^{\mathrm{c}, \mathrm{d}}(0.10)$ & $0.44^{\mathrm{c}, \mathrm{d}}(0.11)$ \\
\hline & $\mathrm{N}$ & $0.39^{\mathrm{c}, \mathrm{d}, \mathrm{e}}(0.01)$ & $0.64^{\mathrm{b}}(0.12)$ & $0.80^{\mathrm{a}}(0.35)$ & $0.25^{\mathrm{d}, \mathrm{e}, \mathrm{f}}(0.03)$ & $0.59^{\mathrm{b}, \mathrm{c}}(0.09)$ & $0.16^{\mathrm{f}}(0.05)$ \\
\hline \multirow[t]{2}{*}{ Vanillic acid } & $\mathrm{S}$ & $1.02^{\mathrm{c}, \mathrm{d}}(0.43)$ & $2.20^{\mathrm{a}}(0.58)$ & $1.29^{\mathrm{b}}(0.41)$ & $0.60^{\mathrm{e}}(0.13)$ & $1.20^{\mathrm{b}, \mathrm{c}, \mathrm{d}}(0.26)$ & $2.04^{\mathrm{a}}(0.51)$ \\
\hline & $\mathrm{N}$ & $0.48^{\mathrm{e}}(0.05)$ & $1.26^{\mathrm{b}, \mathrm{c}}(0.41)$ & $1.45^{\mathrm{b}}(0.67)$ & $0.48^{\mathrm{e}}(0.16)$ & $0.84^{\mathrm{d}, \mathrm{e}}(0.10)$ & $0.93^{\mathrm{d}}(0.71)$ \\
\hline \multirow[t]{2}{*}{ Caffeic acid } & $\mathrm{S}$ & $0.24^{\mathrm{b}}(0.21)$ & $0.33^{\mathrm{b}}(0.16)$ & $0.10^{\mathrm{d}, \mathrm{e}}(0.08)$ & $0.15^{\mathrm{c}, \mathrm{d}}(0.04)$ & n.a. & $0.16^{\mathrm{cdd}}(0.19)$ \\
\hline & $\mathrm{N}$ & $0.09^{\mathrm{d}, \mathrm{e}}(0.09)$ & $0.23^{\mathrm{b}, \mathrm{c}}(0.04)$ & $0.10^{\mathrm{d}, \mathrm{e}}(0.04)$ & $0.08^{\mathrm{d}, \mathrm{e}}(0.05)$ & $0.03^{\mathrm{e}}(0.03)$ & $0.03^{\mathrm{e}}(0.01)$ \\
\hline \multirow[t]{2}{*}{ Syringic acid } & $\mathrm{S}$ & $0.36^{\mathrm{e}}(0.22)$ & $0.79^{\mathrm{a}}(0.29)$ & $0.58^{\mathrm{c}}(0.18)$ & $0.01^{\mathrm{g}}(0.01)$ & $0.40^{\mathrm{d}}(0.04)$ & $0.08^{\mathrm{g}}(0.09)$ \\
\hline & $\mathrm{N}$ & $0.21^{\mathrm{e}, \mathrm{f}}(0.01)$ & $0.63^{\mathrm{b}, \mathrm{c}}(0.08)$ & $0.67^{\mathrm{b}}(0.12)$ & $0.09^{\mathrm{f}, \mathrm{g}}(0.15)$ & n.a. & $0.04^{\mathrm{g}}(0.04)$ \\
\hline \multirow[t]{2}{*}{$p$-coumaric acid } & $\mathrm{S}$ & $0.40^{\mathrm{c}}(0.18)$ & $0.30^{\mathrm{d}, \mathrm{e}}(0.16)$ & $0.09^{\mathrm{h}}(0.04)$ & $0.53^{\mathrm{b}}(0.08)$ & $0.22^{\mathrm{f}}(0.04)$ & $0.11^{\mathrm{g}}(0.05)$ \\
\hline & $\mathrm{N}$ & $0.23^{\mathrm{e}, \mathrm{f}}(0.09)$ & $0.23^{\mathrm{e}, \mathrm{f}}(0.07)$ & $0.08^{\mathrm{h}}(0.04)$ & $0.36^{\mathrm{c}, \mathrm{d}}(0.20)$ & n.a. & $0.12^{\mathrm{g}}(0.04)$ \\
\hline \multirow[t]{2}{*}{ Ferulic acid } & $\mathrm{S}$ & $0.59^{\mathrm{a}}(0.28)$ & $0.47^{\mathrm{a}}(0,30)$ & $0.31^{\mathrm{b}}(0.20)$ & $0.42^{\mathrm{a}, \mathrm{b}}(0.15)$ & $0.26^{\mathrm{b}}(0.10)$ & $0.25^{\mathrm{b}}(0.16)$ \\
\hline & $\mathrm{N}$ & $0.50^{\mathrm{a}}(0.09)$ & $0.51^{\mathrm{a}}(0.04)$ & $0.33^{\mathrm{b}}(0.08)$ & $0.57^{\mathrm{a}}(0.01)$ & n.a. & $0.14^{\mathrm{b}}(0.06)$ \\
\hline \multirow[t]{2}{*}{$o$-coumaric acid } & $\mathrm{S}$ & $0.27^{\mathrm{a}}(0.23)$ & n.a. & $0.27^{\mathrm{a}}(0.23)$ & n.a. & n.a. & n.a. \\
\hline & $\mathrm{N}$ & $0.07^{\mathrm{a}, \mathrm{b}}(0.02)$ & $0.28^{\mathrm{a}}(0.08)$ & $0.05^{\mathrm{c}}(0.04)$ & n.a. & n.a. & $0.34^{\mathrm{a}}(0.18)$ \\
\hline \multirow[t]{2}{*}{ Oleuropein } & S & $2.37^{\mathrm{a}, \mathrm{b}}(1.84)$ & n.a. & $3.49^{\mathrm{a}}(3.23)$ & $2.89^{\mathrm{a}, \mathrm{b}}(0.66)$ & $1.07^{\mathrm{b}}(0.44)$ & $3.35^{\mathrm{a}}(2.31)$ \\
\hline & $\mathrm{N}$ & $1.53^{\mathrm{b}}(0.35)$ & n.a. & $3.02^{\mathrm{a}, \mathrm{b}}(0.86)$ & $4.18^{\mathrm{a}}(3.15)$ & $3.18^{\mathrm{a}, \mathrm{b}}(0.26)$ & $3.10^{\mathrm{a}, \mathrm{b}}(2.06)$ \\
\hline \multirow[t]{2}{*}{ Total phenols ${ }^{* * * *}$} & $\mathrm{~S}$ & 516 & 301 & 254 & 1589 & 1246 & 1230 \\
\hline & $\mathrm{N}$ & 419 & 365 & 254 & 1481 & 1071 & 1339 \\
\hline \multirow[t]{2}{*}{ Ripening index } & $\mathrm{S}$ & 1.33 & 3.73 & 3.53 & 1.2 & 4.56 & 4.87 \\
\hline & $\mathrm{N}$ & 1.27 & 4.57 & 4.13 & 1.2 & 3.97 & 4.36 \\
\hline
\end{tabular}

A.L., agroclimatic location; S, south (about $10 \mathrm{~m}$ above sea level); N, north (about $300 \mathrm{~m}$ above sea level); n.a., not accessed, *from Šindrak et al. (2007), ${ }^{* *} \mathrm{mg}$ caffeic acid equivalent $\cdot \mathrm{kg}^{-1}$ olive oil. Results are means of at least three VOO values (standard deviation), the means within each row (including both S,N producing area), labeled by different letters, are significantly different (Duncan's test, $p \leq 0.05$ ). Some data are missing, related to poorly defined peaks in chrometograms, due to the presence of other complex phenolic compounds.

be seen from the correlation test and PC analysis (see below). Thus, although the ripening index was significantly lower in the case of the cultivar Bjelica than that for Buža and Leccino, both hydroxytyrosol and tyrosol and total phenolic content of Bjelica are greater than those for Buža and Leccino and this holds for the rainy and drought crop year as well. Furthermore, while the observed content of hydroxytyrosol and total phenolics for cultivars Bjelica and Leccino were much greater in the drought than in the rainy year, the opposite could be seen for tyrosol and there is a difference in the content of hydroxytyrosol with regard to the Buža cultivar. Following an investigation comprising four successive crop seasons, Romero et al. (2003) concluded that phenolic profiles were mainly influenced by cumulative rainfall. Similarly, Ilyasoglu et al. (2010) found that the total phenolic contents of some Aegean VOO-s are greater in the drought than in the rainy crop year, but their observed range of variation is much smaller than that observed in this study. It seems that the total phenolic content could depend less on the plantation area but is much more characteristic of the cultivar and strongly depends on the climate characteristics of the year (see also the above mentioned case of Leccino). In this context some findings of 
TABLE 2. Phenolic compounds $\left(\mathrm{mg}_{\mathrm{K}} \cdot \mathrm{kg}^{-1}\right)$ in virgin olive oils from the Croatian cultivars Plominka, Zižolera, Oblica and Lastovka

\begin{tabular}{lcccc}
\hline Phenolic compound $^{\mathbf{a}}\left(\mathbf{m g} \cdot \mathbf{k g}^{\mathbf{- 1}}\right)$ & Plominka $^{\mathbf{b}}$ & Žižolera $^{\mathbf{c}}$ & Oblica $^{\mathbf{d}}$ & Lastovka $^{\mathbf{d}}$ \\
\hline Hydroxytyrosol & 7.22 & 5.07 & 6.24 & 16.29 \\
Tyrosol & 5.26 & 4.35 & 32.61 & 12.46 \\
3,4dihydroxybenzoic acid & 0.02 & 0.16 & 0.37 & n.a. \\
p-hydroxybenzoic acid & 0.05 & 0.10 & n.a. & n.a. \\
Homovanillyl alcohol & 0.25 & 0.35 & 0.72 & 0.30 \\
Vanillic acid & 1.90 & 0.56 & 0.18 & 0.30 \\
Caffeic acid & 0.17 & 0.09 & n.a. & n.a. \\
Syringic acid & 0.02 & 0.05 & n.a. & n.a. \\
p-coumaric acid & 0.32 & 0.43 & 0.81 & 0.80 \\
Ferulic acid & n.a. & n.a. & 0.52 & 0.24 \\
Oleuropein & 7.61 & 3.97 & 2.37 & n.a. \\
\hline
\end{tabular}

${ }^{\mathrm{a}} 2^{\text {nd }}$ year; ${ }^{\mathrm{b}}$ island $\mathrm{Cres} ;{ }^{\mathrm{c}} \mathrm{Pula}$ (agroclimatic location south), about 300 year old trees; ${ }^{\mathrm{d}}$ island Hvar

Tura et al. (2009) may be of interest; they suggested that the cultivation sites did not affect oil composition and profile of EVOO of the same cultivar in the same crop year. However, Table 1 shows the concentrations of a majority of individual phenols in the EVOO-s to be greater in oils from the southern location. This seems not to be unexpected since environments where olive trees grow may likely influence plant physiology as well as the olive ripening process and subsequently the phenolic profiles. Here, it might be noted that, for example, the finding of a total phenolic content of $1589 \mathrm{mg} \cdot \mathrm{kg}^{-1}$ of EVOO in the Bjelica cultivar from Pula (Barbariga) is consistent with the historically well known great appreciation that the olive oil from the Istra peninsula received from the ages of the Roman Empire. To emphasize this issue, as well as, for example, the unusually high concentration of tyrosol in the EVOO (see below) could be additional line within the intended framework for a more innovative labeling of EVOO aimed at being presented as a food supplement.

The examined EVOO-s from the cultivar Bjelica have very high concentrations of tyrosol in some cases. While the observed concentrations range from $3 \mathrm{mg} \cdot \mathrm{kg}^{-1}$ to $140 \mathrm{mg} \cdot \mathrm{kg}^{-1}$ of tyrosol, the reported average value of the tyrosol content in VOO-s from the 23 samples from Spain, Italy, Greece and Tunisia (Hrncirik et al., 2004) is tenfold or even lower than our upper value for this phenol. This upper value presents one of the highest observed contents of tyrosol in an EVOO and values well below $13 \mathrm{mg} \cdot \mathrm{kg}^{-1}$ of tyrosol were often reported (Ramos-Escudero et al., 2015, Bajoub et al., 2015, Ballus et al., 2015). Given the great biomedicinal potential of tyrosol suggested which, among others involves antioxidants, Cicerale et al. (2012), neuroprotective, Vauzour et al. (2010), cardiovascular Nakbi et al. (2011), antimicrobial, Karaosmanoglu et al. (2010), anti-inflammatory, Lu et al. (2013), Cárdeno et al. (2014), antigenotoxic,
Anter et al. (2014), to mention only a few, future selection of the olives based on the presented results could be of use to obtain oils which are more abundant in particular simple phenol compounds.

The presence of biomedicinally important "minor" phenolic compounds such as $p$-coumaric, caffeic acid, homovanillyl alcohol, vanilic acid and others in the examined EVOO-s (see Table 1 and 2) should be of particular interest. Because of, for instance, beneficial anticancer effects, Nichenametla et al. (2006), antiinflammatory potential, Pragasam et al. (2013) potential beneficial effects in treating metabolic disorders, Yoon et al. (2013), antibacterial effects, Lou et al. (2012) and a possible preventive effect on myocardial infarct size, Roy et al. (2013) of p-coumaric acid, or the beneficial effects of caffeic acid, El Seedi et al. (2012), Vauzour et al. (2010), da Cunha et al. (2004), these and other "minor" phenolics should be an inevitable part in the new labeling framework.

Here, a feasibility of using a back-label on EVOO bottles to additionally quote scientific references (perhaps including citation of short statements from such references) is under consideration. Namely, in the case of olive oil, European Regulation 432/2012 states that the health effect can be claimed only if the oil contains more than $5 \mathrm{mg}$ of hydroxytyrosol and its derivatives (e.g., oleuropein complex and tyrosol) in $20 \mathrm{~g}$ of oil, but the quotation of scientific references is not explicitly forbidden.

The phenolic profiles of EVOO-s of the autochthonous cultivars Plominka, Žižolera, Oblica and Lastovka (Table 2) are not very different from those of Buža and Bjelica. It could be noted that Oblica is the most represented olive variety in Croatia. Table 2 shows fairly high concentrations of tyrosol, hydroxytyrosol and $p$-coumaric acid both in EVOO-s of Oblica and Lastovka. The case of Žižolera could be of some interest because oil from three hundred year olives was examined. Namely, there are at the 
island of Pag (Lun, about $50 \mathrm{~km}$ to the south-east of the Istra peninsula) about 1000 very old olive trees (mainly of the autochthonous Croatian varieties Mastrinka and Oblica); the majority of these olives comprise trees older than 700 years, and there is also a sizable group of trees more than 1000 years old. Their location is of special interest within the framework of the incentive mentioned at the beginning. It should be noted that the European Community (EC) Council of Regulation established compulsory standards for olive oil production with regard to labeling (European Commission Regulation 182/2009, $c f$. in references); the regulation has compelling virgin and extra-virgin olive oil producers to indicate the geographical location of olive harvesting and oil production on the label, but the age of the olive trees is not involved. There are thousands of very old autochthonous olive orchards across the Croatian Adriatic coast and islands.

A correlation test involving data obtained from the analysis of the phenolic profile of EVOO-s from the cultivars Bjelica, Buža and Leccino (Tables 1, 3, $4,5)$ shows significant characteristic correlation profiles pertaining to a particular cultivar. It could be speculated that the relationships among phenolic compounds reflect more complex relationships between genetic and biosynthetic patterns, thus describing the "identity" of a particular olive variety.

Recently, Tura et al. (2007) and El Riachy et al. (2012a) reported the correlation between tyrosol

TABLE 3. Pearson correlation among individual phenols, data obtained for the cultivar Bjelica

\begin{tabular}{|c|c|c|c|c|c|c|c|c|c|c|c|}
\hline & OHtyr & tyr & $3,40 \mathrm{Ob}$ & pOHb & hva & va & ca & sa & pcoa & fa & ole \\
\hline OHtyr & 1 & & & & & & & & & & \\
\hline tyr & n.s. & 1 & & & & & & & & & \\
\hline $3,4 \mathrm{OHb}$ & n.s. & n.s. & 1 & & & & & & & & \\
\hline$p \mathrm{OHb}$ & n.s. & n.s. & $0.827^{* *}$ & 1 & & & & & & & \\
\hline hva & n.s. & $0.827 * *$ & $0.822^{* *}$ & $0.916^{* *}$ & 1 & & & & & & \\
\hline va & n.s. & n.s. & n.s. & $0.698 * *$ & n.s. & 1 & & & & & \\
\hline ca & n.s. & n.s. & n.s. & $0.800 * *$ & n.s. & $0.795^{* *}$ & 1 & & & & \\
\hline sa & n.s. & n.s. & n.s. & n.s. & n.s. & n.s. & n.s. & 1 & & & \\
\hline pcoa & n.s. & n.s. & n.s. & n.s. & n.s. & $0.761 * *$ & n.s. & n.s. & 1 & & \\
\hline $\mathrm{fa}$ & n.s. & n.s. & n.s. & n.s. & n.s. & n.s. & n.s. & n.s. & $0.695^{* *}$ & 1 & \\
\hline ole & n.s. & n.s. & n.s. & n.s. & n.s. & n.s. & n.s. & n.s. & n.s. & n.s. & 1 \\
\hline
\end{tabular}

n.s., not significant; **, significant at $p \leq 0.01$.

OHtyr, hydroxytyrosol; tyr, tyrosol; 3,4OHb, 3,4dihydroxybenzoic acid; $p \mathrm{OHb}$, $p$-hydroxybenzoic acid; hva, homovanillyl alcochol; va, vanillic acid; ca, caffeic acid; sa, syringic acid; $p$ coa, $p$-coumaric acid; fa, ferulic acid; ole, oleuropein.

TABLE 4. Pearson correlation among individual phenols, data obtained for the cultivar Buža

\begin{tabular}{|c|c|c|c|c|c|c|c|c|c|c|c|}
\hline & OHtyr & tyr & $3,40 H b$ & $p \mathrm{OHb}$ & hva & va & ca & sa & pcoa & fa & ole \\
\hline OHtyr & 1 & & & & & & & & & & \\
\hline tyr & n.s. & 1 & & & & & & & & & \\
\hline $3,4 \mathrm{OHb}$ & n.s. & $0.963 * *$ & 1 & & & & & & & & \\
\hline pOHb & n.s. & n.s. & n.s. & 1 & & & & & & & \\
\hline hva & n.s. & n.s. & n.s. & n.s. & 1 & & & & & & \\
\hline va & n.s. & n.s. & n.s. & n.s. & n.s. & 1 & & & & & \\
\hline ca & n.s. & n.s. & n.s. & $0.824^{* *}$ & n.s. & n.s. & 1 & & & & \\
\hline sa & n.s. & n.s. & n.s. & n.s. & n.s. & $0.751^{* *}$ & n.s. & 1 & & & \\
\hline pcoa & n.s. & n.s. & n.s. & n.s. & n.s. & n.s. & n.s. & $0.661^{*}$ & 1 & & \\
\hline fa & n.s. & n.s. & n.s. & n.s. & n.s. & n.s. & $0.727^{*}$ & $0.800^{* *}$ & n.s. & 1 & \\
\hline ole & n.s. & n.s. & n.s. & n.s. & n.s. & n.s. & n.s. & n.s. & n.s. & n.s. & 1 \\
\hline
\end{tabular}

n.s., not significant; *, significant at $p \leq 0.05 ; * *$, significant at $p \leq 0.01$.

OHtyr, hydroxytyrosol; tyr, tyrosol; 3,4OHb, 3,4dihydroxybenzoic acid; $p \mathrm{OHb}$, $p$-hydroxybenzoic acid;

hva, homovanillyl alcochol; va, vanillic acid; ca, caffeic acid; sa, syringic acid; $p$ coa, $p$-coumaric acid; fa, ferulic acid; ole, oleuropein. 
Labeled extra virgin olive oil as food supplement; phenolic compounds in oils from some autochthonous Croatian olives $\bullet$

TABLE 5. Pearson correlation among individual phenols, data obtained for the cultivar Leccino

\begin{tabular}{|c|c|c|c|c|c|c|c|c|c|c|c|}
\hline & OHtyr & tyr & $3,40 H b$ & $p \mathrm{OHb}$ & hva & va & ca & sa & pcoa & fa & ole \\
\hline OHtyr & 1 & & & & & & & & & & \\
\hline tyr & n.s. & 1 & & & & & & & & & \\
\hline $3,4 \mathrm{OHb}$ & n.s. & $0.400^{*}$ & 1 & & & & & & & & \\
\hline$p \mathrm{OHb}$ & n.s. & n.s. & n.s. & 1 & & & & & & & \\
\hline hva & n.s. & n.s. & n.s. & $0.702^{* *}$ & 1 & & & & & & \\
\hline va & n.s. & n.s. & n.s. & n.s. & $0.653^{* *}$ & 1 & & & & & \\
\hline ca & n.s. & n.s. & n.s. & n.s. & $0.588^{* *}$ & & 1 & & & & \\
\hline sa & n.s. & n.s. & n.s. & $0.593^{* *}$ & $0.666^{* *}$ & $0.899 * *$ & n.s. & 1 & & & \\
\hline pcoa & n.s. & n.s. & n.s. & n.s. & n.s. & n.s. & n.s. & $0.764 * *$ & 1 & & \\
\hline fa & n.s. & n.s. & n.s. & n.s. & n.s. & $0.741 * *$ & n.s. & n.s. & n.s. & 1 & \\
\hline ole & n.s. & n.s. & n.s. & n.s. & n.s. & $0.798 * *$ & n.s. & $0.875^{* *}$ & n.s. & $0.946^{* *}$ & 1 \\
\hline
\end{tabular}

n.s., not significant; $*$, significant at $p \leq 0.05 ; * *$, significant at $p \leq 0.01$.

OHtyr, hydroxytyrosol; tyr, tyrosol; 3,4OHb, 3,4dihydroxybenzoic acid; $p \mathrm{OHb}$, $p$-hydroxybenzoic acid; hva, homovanillyl alcochol; va, vanillic acid; ca, caffeic acid; sa, syringic acid; $p$ coa, $p$-coumaric acid; fa, ferulic acid; ole, oleuropein.

and vanillic acid, and El Riachy et al. (2012b) the correlation between vanilic acid and $p$-coumaric acid, ascribing the findings to the same biosynthetic pathway of these compounds.

A principal component analysis (PCA) also was carried out in an attempt to explore some underlying pattern that may be taken as a source of variation in EVOO phenolic compound composition.

The data set for different cultivars, involving two different agroclimatic locations and obtained over two harvest years that differ significantly in the amount of rainfall, regarding the variables of phenolics was subjected to PCA to investigate possible grouping of samples on the basis of cultivar, harvest year and agroclimatic location.

PCA showed that $68 \%$ of the total variance was associated with the first three principal components. The first component accounted for $33.5 \%$ of the total variance, with a high positive correlation with 3,4dihydroxybenzoic acid, $p$-hydroxybenzoic acid, homovanillyl alcohol and syringic acid; the second component accounted for $21.5 \%$ of the total variance and was positively correlated to tyrosol, hydroxytyrosol, $p$-coumaric and ferulic acid and the third component accounted for $13.4 \%$ of the total variance with a high positive correlation with vanillic and caffeic acid.

The biplot on PC1 and PC2 (Figure 1), explaining $55 \%$ of the total variance, allows for differentiation of the two groups according to harvest year mainly on the basis of the first principal component values. Almost all EVOO samples from the rainy harvest year have positive scores for the first component, while almost all drought year EVOO samples have negative scores. There is also obvious differentiation taking into regard cultivar, mainly on the basis of the second principal component values. All EVOO samples corresponding to the Bjelica cultivar have positive scores for the second component, while $B u z \check{a} a$ and Leccino samples have negative scores. Furtherly, there is differentiation between Buža and Leccino samples, with Buža samples found between Bjelica and Leccino. The biplot on PC1 and PC3 (Figure 2), explaining $47 \%$ of the total variance, also shows good separation of samples regarding harvest year, while in the biplot on PC2 and PC3 (Figure 3), explaining $35 \%$ of the total variance, the grouping is less obvious. Regarding cultivar, the biplot on PC2 and PC3 shows good grouping of the Bjelica cultivar and some overlap between Leccino and Buža; while in the

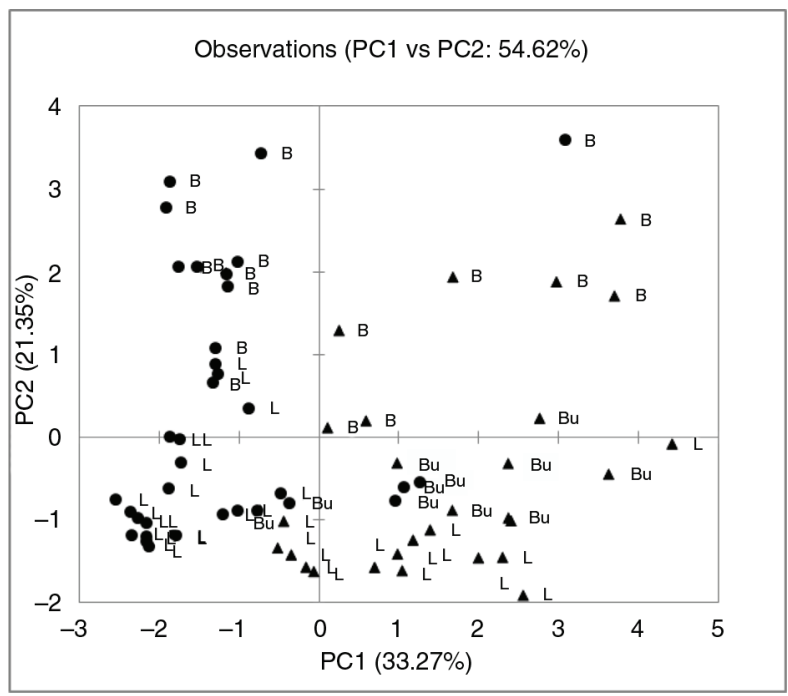

FIGURE 1. The score-plot of samples from principal component

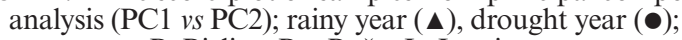
$\mathrm{B}$, Bjelica; Bu, Buža; L, Leccino. 


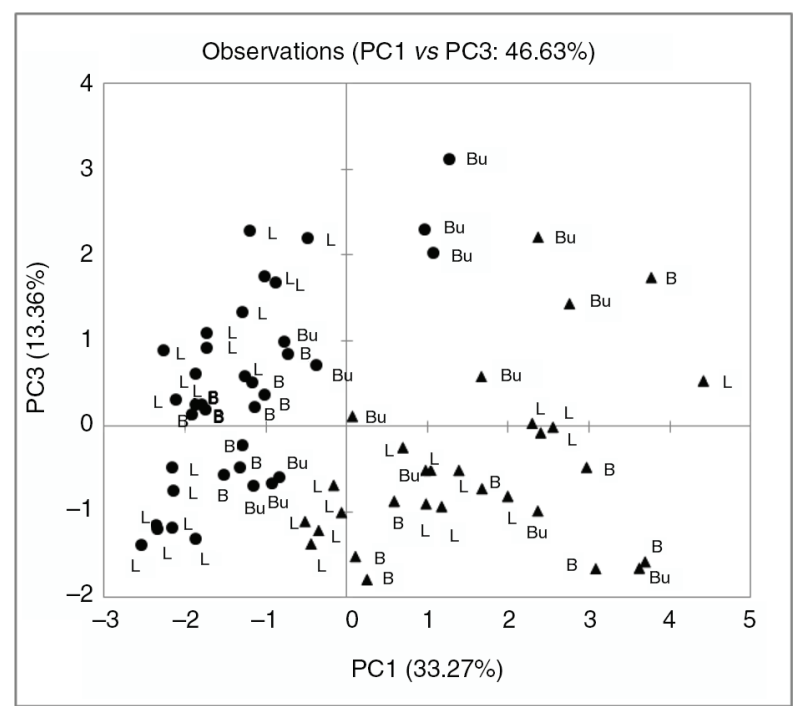

FIGURE 2. The score-plot of samples from principal component

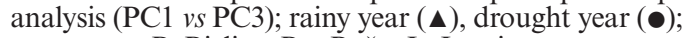
B, Bjelica; Bu, Buža; L, Leccino.

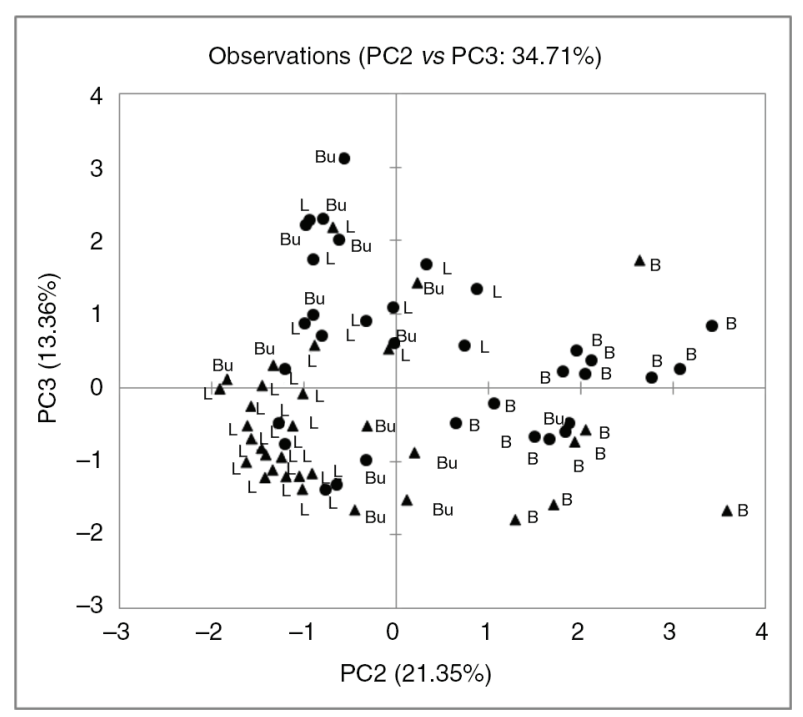

FIGURE 3. The score-plot of samples from principal component analysis (PC2 vs PC3); rainy year ( $\mathbf{\Lambda})$, drought year $(\bullet)$; $\mathrm{B}$, Bjelica; Bu, Buža; L, Leccino.

biplot on PC1 and PC3 there is no obvious grouping of different cultivars. Interestingly, and consistent with some of the mentioned considerations (see above) regarding agroclimatic location, there is no significant differentiation in the score plots.

\section{CONCLUSIONS}

Phenolic profile analyses of the extra virgin olive oils obtained from the three autochthonous Croatian olive cultivars, Buža, Plominka and Žižolera, and the domesticated cultivar Bjelica, are reported for the first time. The analyses have been performed within the framework of an incentive that has been considered to provide labeled extra virgin olive oils as a food supplement in pharmacies, in order to extend the consumption of EVOO-s in northern Croatia. The obtained data, also involving a correlation test and the insight from PCA reveal that the cultivars are highly individualized in character with regard to relationships among phenolic compounds. This finding as well as the observation of very significant differences in the content of phenolic compounds between the rainy and successive drought crop years will be of importance for targeted acquisition and perhaps the price of the oils. The observation of an extremely high concentration of tyrosol in some cases can be useful not only for future selection of the olives to obtain oils which are more abundant in a particular simple phenol compound. While the information on the most important phenolic compounds and the total phenolic content should be a part of the main label, on the back-label of EVOO bottles appropriate biomedicinally important scientific references (perhaps including citation of short statements from such references) with regard to selected and especially abundant phenolic compound(s) in the oil could be additionally quoted. The information on the variety used, the age of very old olive trees, the location of orchard and the harvest year should follow a tendency toward an innovative labeling aimed at better presenting the authenticity, quality, excellence and uniqueness of the EVOO-s. Finally, the issue reported also seems to be consistent with the The Framework Programme for Research and Innovation - 2014-2020 of the European Commission, promoted as a research program aimed at preserving the image of olive oil and to guarantee its quality and authenticity. A very important issue related to the uniqueness, authenticity and quality of EVOO-s is the question of the aromatic profile of oils (Reboredo-Rodríguez et al., 2012, 2013a,b,c, 2014a,b); although not elaborated in this study, it should be an unavoidable part of subsequent future work in the matter.

\section{ACKNOWLEDGMENTS}

We thank the Croatian ministry of science and education for the financial support (project 0178052).

\section{REFERENCES}

Anter J, Tasset I, Demyda-Peyrás S, Ranchal I, Moreno-Millán M, Romero-Jimenez M, Muntané J, Luque de Castro MD, Muñoz-Serrano A, Alonso-Moraga A. 2014. Evaluation of potential antigenotoxic, cytotoxic and proapoptotic effects of the olive oil by-product "alperujo", hydroxytyrosol, tyrosol and verbascoside. Mutat Res-Gen Tox En 772, 25-33. http://dx.doi.org/10.1016/j.mrgentox.2014.07.002.

Bajoub A, Carrasco-Pancorbo A, AjalEA, Ouazzani N, FernándezGutiérrez A. 2015. Potential of LC-MS phenolic profiling 
combined with multivariate analysis as an approach for the determination of the geographical origin of north Moroccan virgin olive oils. Food Chem. 166, 292-300. http://dx.doi. org/10.1016/j.foodchem.2014.05.153.

Ballus CA, Quirantes-Pine R, Bakhouche A, de Oliveira da Silva LF, de Oliveira AF, Coutinho EF, da Croce DM, SeguraCarretero A, Godoy HT. 2015. Profile of phenolic compounds of Brazilian virgin olive oils by rapid resolution liquid chromatography coupled to electrospray ionisation timeof-flight mass spectrometry (RRLC-ESI-TOF-MS). Food Chem. 170, 366-377. http://dx.doi.org/10.1016/j.foodchem. 2014.08.054.

Cabrerizo S, De La Cruz JP, López-Villodres JA, Muñoz-Marín J, Guerrero A, Reyes JJ, Labajos MT, González-Correa JA. 2013. Role of the inhibition of oxidative stress and inflammatory mediators in the neuroprotective effects of hydroxytyrosol in rat brain slices subjected to hypoxia reoxygenation. J. Nutr. Biochem. 24, 2152-2157. http://dx.doi.org/10.1016/j. jnutbio.2013.08.007.

Cárdeno A, Sánchez-Hidalgo M, Aparicio-Soto M, SánchezFidalgo S, Alarcón de la Lastra C. 2014. Extra virgin olive oil polyphenolic extracts downregulate inflammatory responses in LPS-activated murine peritoneal macrophages suppressing NFKB and MAPK signalling pathways. Food Funct. 5, 1270-1277. http://dx.doi.org/10.1039/c4fo00014e.

Cicerale S, Lucas L, Keast R. 2012. Antimicrobial, antioxidant and anti-inflammatory phenolic activities in extra virgin olive oil. Curr. Opin. Biotech. 23, 129-135. http://dx.doi.org/10.1016/j. copbio.2011.09.006.

Clodoveo ML, Camposeo S, de Gennaro B, Pascuzzi S, Roselli L. 2014. In the ancient world, virgin olive oil was called "liquid gold" by Homer and "the great healer" by Hippocrates. Why has this mythic image been forgotten? Food Res. Int. 62, 1062-1068. http://dx.doi.org/10.1016/j. foodres.2014.05.034.

da Cunha FM, Duma D, Assreuy J, Buzzi FC, Niero R, Campos MM, Calixto J. 2004. Caffeic Acid Derivatives: In Vitro and In Vivo Anti-inflammatory Properties. Free Radical Res. 38, 1241-1253. http://dx.doi.org/10.1080/10715760400016139.

El Riachy M, Priego-Capote F, Rallo L, Luque de Castro MD, León L. 2012. Phenolic profile of virgin olive oil from advanced breeding selections. Span J. Agric. Res. 10, 443-453. http://dx.doi.org/10.5424/sjar/2012102-264-11.

El Riachy M, Priego-Capote F, León L, Luque de Castro MD, Rallo L. 2012. Virgin olive oil phenolic profile and variability in progenies from olive crosses. J. Sci. Food Agric. 92, 2524-2533. http://dx.doi.org/10.1002/jsfa.5662.

El-Seedi HR, El-Said A, Khalifa S, Goransson U, Bohlin L, BorgKarlson AK, Verpoorte R. 2012. Biosynthesis, Natural Sources, Dietary Intake, Pharmacokinetic Properties, and Biological Activities of Hydroxycinnamic Acids. J. Agric. Food Chem. 60, 10877-10895. http://dx.doi.org/10.1021/ jf301807g.

Espín JC, Soler-Rivas C, Cantos E, Tomás-Barberán FA, Wichers HJ. 2001. Synthesis of the Antioxidant Hydroxytyrosol Using Tyrosinase as Biocatalyst. J. Agric. Food Chem. 49, 1187-1193. http://dx.doi.org/10.1021/jf001258b.

Estruch R, Ros E, Salas-Salvadó J, Covas MI, Corella D, Arós F, Gómez-Gracia E, Ruiz-Gutiérrez V, Fiol M, Lapetra J, Lamuela-Raventos RM, Serra-Majem L, Pintó X, Basora J, Muñoz MA, Sorlí JV, Martínez JA, Martínez-González MA. 2013. Primary Prevention of Cardiovascular Disease with a Mediterranean Diet. New Engl. J. Med. 368, 1279-1290. http://dx.doi.org/10.1056/NEJMoa1200303.

European Commission. 2009. Commission Regulation (EC) No 182/2009 of 6 March 2009. amending Regulation (EC) No. 1019/2002 on marketing standards for olive oil. Off. J. Eur. Union L 63, 6-8.

European Commission. 2012. Commission Regulation (EU) No 432/2012 of 16 May 2012. establishing a list of permitted health claims made on foods, other than those referring to the reduction of disease risk and to children's development and health. Off. J. Eur. Union L 136, 1-40.

Fung TT, Rexrode KM, Mantzoros CS, Manson JE, Willett WC, Hu FB. 2009. Mediterranean Diet and Incidence of and Mortality From Coronary Heart Disease and Stroke in Women. Circulation 119, 1093-1100. http://dx.doi.org/ 10.1161/CIRCULATIONAHA.108.816736.

García-Martínez O, Mazzaglia G, Sánchez-Ortiz A, OcañaPeinado FM, Rivas A. 2014. Phenolic content of Sicilian virgin olive oils and their effect on MG-63 human osteoblastic cell proliferation. Grasas Aceites 65, e032. http:// dx.doi.org/10.3989/gya.0111141.

García-Martínez O, Rivas A, Ramos-Torrecillas J, De LunaBertos E, Ruiz C. 2014. The effect of olive oil on osteoporosis prevention. Int. J. Food Sci. Nutr. 65, 834-840. http:// dx.doi.org/10.3109/09637486.2014.931361

Giordano E, Davalos A, Nicod N, Visioli F. 2014. Hydroxytyrosol attenuates tunicamycin-induced endoplasmic reticulum stress in human hepatocarcinoma cells. Mol. Nutr. Food Res. 58, 954-962. http://dx.doi.org/10.1002/mnfr.201300465.

Hashim YZY, Rowland IR, McGlynn H, Servili M, Selvaggini R, Taticchi A, Esposto S, Montedoro G, Kaisalo L, Wähälä K, Gill CIR. 2008. Inhibitory effects of olive oil phenolics on invasion in human colon adenocarcinoma cells in vitro. Int. J. Cancer 122, 495-500. http://dx.doi.org/10.1002/ijc.23148.

Hashim YZHY, Worthington J, Allsopp P, Ternan NG, Brown EM, McCann MJ, Rowland IR, Esposto S, Servili M, Gill CIR. 2014. Virgin olive oil phenolics extract inhibit invasion of HT115 human colon cancer cells in vitro and in vivo. Food Funct. 5, 1513-1519. http://dx.doi.org/10.1039/ c4fo00090k.

Hrncirik K, Fritsche S. 2004. Comparability and reliability of different techniques for the determination of phenolic compounds in virgin olive oil. Eur. J. Lipid Sci. 106, 540-549. http://dx.doi.org/10.1002/ejlt.200400942.

Ilyasoglu H, Ozcelik B, Van Hoed V, Verhe R. 2010. Characterization of Aegean Olive Oils by Their Minor Compounds. J. Am. Oil Chem. Soc. 87, 627-636. http:// dx.doi.org/10.1007/s11746-009-1538-5.

Karaosmanoglu H, Soyer F, Ozen B, Tokatli F. 2010. Antimicrobial and Antioxidant Activities of Turkish Extra Virgin Olive Oils. J. Agric. Food Chem. 58, 8238-8245. http:// dx.doi.org/10.1021/jf1012105.

Keys A. 1970. Coronary Heart Disease in 7 Countries. Circulation 41, I86-195.

Lamy S, Ouanouki A, Béliveau R, Desrosiers RR. 2014. Olive oil compounds inhibit vascular endothelial growth factor receptor-2 phosphorylation. Exp. Cell Res. 322, 89-98. http://dx.doi.org/10.1016/j.yexcr.2013.11.022.

Lipworth L, Martinez ME, Angell J, Hsieh CC, Trichopoulos D. 1997. Olive oil and Human Cancer: An Assessment of the Evidence. Prev. Med. 26, 181-190. http://dx.doi.org/10.1006/ pmed.1996.9977.

López-Miranda J, Pérez-Jiménez F, Ros E, De Caterina R, Badimón L, Covas MI, Escrich E, Ordovás JM, Soriguer F, Abiá R, Alarcón de la Lastra C, Battino M, Corella D, Chamorro-Quirós J, Delgado-Lista J, Giugliano D, Esposito K, Estruch R, Fernandez-Real JM, Gaforio JJ, La Vecchia C, Lairon D, López-Segura F, Mata P, Menéndez JA, Muriana FJ, Osada J, Panagiotakos DB, Paniagua JA, Pérez-Martinez P, Perona J, Peinado MA, Pineda-Priego M, Poulsen HE, Quiles JL, Ramírez-Tortosa MC, Ruano J, Serra-Majem L, Solá R, Solanas M, Solfrizzi V, de la Torre-Fornell R, Trichopoulou A, Uceda M, Villalba-Montoro JM, VillarOrtiz JR, Visioli F, Yiannakouris N. 2010. Olive oil and health: Summary of the II international conference on olive oil and health consensus report, Jaén and Córdoba (Spain) 2008. Nutr. Metab. Cardiovas. 20, 284-294. http://dx.doi.org/ 10.1016/j.numecd.2009.12.007.

Lou Z, Wang H, Rao S, Sun J, Ma C, Li J. 2012. p-Coumaric acid kills bacteria through dual damage mechanisms. Food Control 25, 550-554. http://dx.doi.org/10.1016/j.foodcont. 2011.11.022

Lu J, Huang G, Wang Z, Zhuang S, Xu L, Song B, Xiong Y, Guan S. 2013. Tyrosol exhibits negative regulatory effects on LPS response and endotoxemia. Food Chem. Toxicol. 62, 172-178. http://dx.doi.org/10.1016/j.fct.2013.08.031.

Martínez-González MA, Fernández-Jarne E, Serrano-Martínez M, Marti A, Martinez JA, Martín-Moreno JM. 2002. Mediterranean diet and reduction in the risk of a first acute myocardial infarction: an operational healthy dietary 
score. Eur. J. Nutr. 41, 153-160. http://dx.doi.org/10.1007/ s00394-002-0370-6.

Montedoro G, Servili M, Baldioli M, Miniati E. 1992. Simple and hydrolyzable phenolic compounds in virgin olive oil. 1. Their extraction, separation, and quantitative and semiquantitative evaluation by HPLC. J. Agric. Food Chem. 40, 1571-1576. http://dx.doi.org/10.1021/jf00021a019.

Nakbi A, Dabbou S, Champion S, Fouchier F, Mehri S, Attia N, Leger C, Hammami M. 2011. Modulation of the superoxide anion production and MMP-9 expression in PMA stimulated THP-1 cells by olive oil minor components: Tyrosol and hydroxytyrosol. Food Res. Int. 44, 575-581. http://dx.doi.org/10.1016/j.foodres.2010.12.010.

Nichenametla SN, Taruscio TG, Barney DL, Exon JH. 2006. A review of the effects and mechanisms of polyphenolics in cancer. Crit. Rev. Food Sci. Nutr. 46, 161-183. http:// dx.doi.org/10.1080/10408390591000541.

Oliveras-López MJ, Berná G, Jurado-Ruiz E, López-García de la Serrana H, Martín F. 2014. Consumption of extra-virgin olive oil rich in phenolic compounds has beneficial antioxidant effects in healthy human adults. J. Funct. Foods 10, 475-484. http://dx.doi.org/10.1016/j.jff.2014.07.013.

Owen RW, Mier W, Giacosa A, Hull WE, Spiegelhalder B, Bartsch H. 2000. Phenolic compounds and squalene in olive oils: the concentration and antioxidant potential of total phenols, simple phenols, secoiridoids, lignans and squalene. Food Chem. Toxicol. 38, 647-659. http://dx.doi.org/10.1016/ S0278-6915(00)00061-2.

Paiva-Martins F, Silva A, Almeida V, Carvalheira M, Serra C, Rodrígues-Borges JE, Fernandes J, Belo L, Santos-Silva A. 2013. Protective Activity of Hydroxytyrosol Metabolites on Erythrocyte Oxidative-Induced Hemolysis. J. Agric. Food Chem. 61, 6636-6642. http///dx doi.org/10.1021/jf4016202.

Pragasam SJ, Murunikkara V, Sabina EP, Rasool M. 2013. Ameliorative effect of $p$-coumaric acid, a common dietary phenol, on adjuvant-induced arthritis in rats. Rheumatol. Int. 33, 325-334. http://dx.doi.org/10.1007/s00296-012-2394-4.

Ramos-Escudero F, Teresa Morales M, Asuero AG. 2015. Characterization of Bioactive Compounds from Monovarietal Virgin Olive Oils: Relationship Between Phenolic CompoundsAntioxidant Capacities. Int. J. Food Prop. 18, 348-358. http:// dx.doi.org/10.1080/10942912.2013.809542.

Reboredo-Rodríguez P, González-Barreiro C, Cancho-Grande B, Simal-Gándara J. 2012. Dynamic headspace/GC-MS to control the aroma fingerprint of extra-virgin olive oil from the same and different olive varieties. Food Control 25, 684-695 http://dx.doi.org/10.1016/j.foodcont.2011.12.005.

Reboredo-Rodríguez P, González-Barreiro C, Cancho-Grande B, Simal-Gándara J. 2013. Concentrations of Aroma Compounds and Odor Activity Values of Odorant Series in Different Olive Cultivars and Their Oils. J. Agric. Food Chem. 61, 5252-5259. http://dx.doi.org/10.1021/jf400804m.

Reboredo-Rodríguez P, González-Barreiro C, Cancho-Grande B, Simal-Gándara J. 2013. Aroma biogenesis and distribution between olive pulps and seeds with identification of aroma trends among cultivars. Food Chem. 141, 637-643. http://dx.doi.org/10.1016/j.foodchem.2013.02.095.

Reboredo-Rodríguez P, González-Barreiro C, Cancho-Grande B, Simal-Gándara J. 2013. Effects of Sedimentation Plus Racking Process in the Extra Virgin Olive Oil Aroma Fingerprint Obtained by DHS-TD/GC-MS. Food Bioprocess. Tech. 6 , 1290-1301. http://dx.doi.org/10.1007/s11947-011-0751-z.

Reboredo-Rodríguez P, González-Barreiro C, Cancho-Grande B, Simal-Gándara J. 2014. Improvements in the malaxation process to enhance the aroma quality of extra virgin olive oils. Food Chem. 158, 534-545. http://dx.doi.org/10.1016/j. foodchem.2014.02.140

Reboredo-Rodríguez P, González-Barreiro C, Cancho-Grande B, Simal-Gándara J. 2014. Quality of extra virgin olive oils produced in an emerging olive growing area in northwestern Spain. Food Chem. 164, 418-426. http://dx.doi. org/10.1016/j.foodchem.2014.05.043.

Romero MP, Tovar MJ, Ramo T, Motilva MJ. 2003. Effect of crop season on the composition of virgin olive oil with protected designation of origin "Les Garrigues." J. Am. Oil Chem. Soc. 80, 423-430. http://dx.doi.org/10.1007/ s11746-003-0715-z.

Roy AJ, Prince PSM. 2013. Preventive effects of $p$-coumaric acid on cardiac hypertrophy and alterations in electrocardiogram, lipids, and lipoproteins in experimentally induced myocardial infarcted rats. Food Chem. Toxicol. 60, 348-354. http://dx.doi.org/10.1016/j.fct.2013.04.052.

Scoditti E, Nestola A, Massaro M, Calabriso N, Storelli C, De Caterina R, Carluccio MA. 2014. Hydroxytyrosol suppresses MMP-9 and COX-2 activity and expression in activated human monocytes via $\mathrm{PKC} \alpha$ and $\mathrm{PKC} \beta 1$ inhibition. Atherosclerosis 232, 17-24. http://dx.doi.org/10.1016/j. atherosclerosis.2013.10.017

Sofi F, Abbate R, Gensini GF, Casini A. 2010. Accruing evidence on benefits of adherence to the Mediterranean diet on health: an updated systematic review and meta-analysis1. Am. J. Clin. Nutr. 92, 1189-1196. http://dx.doi.org/10.3945/ ajen.2010.29673.

Šarolić M, Gugić M, Tuberoso C, Jerković I, Šuste M, Marijanović Z, Kuš P. 2014. Volatile Profile, Phytochemicals and Antioxidant Activity of Virgin Olive Oils from Croatian Autochthonous Varieties Mašnjača and Krvavica in Comparison with Italian Variety Leccino. Molecules 19, 881-895. http://dx.doi.org/10.3390/molecules19010881.

Šindrak Z, Benčić Đ, Voća S, Berberić A. 2007. Total phenols in varietal olive oils from Istria. Pomologia Croatica 13, 17-29.

Tura D, Gigliotti C, Pedò S, Failla O, Bassi D, Serraiocco A. 2007. Influence of cultivar and site of cultivation on levels of lipophilic and hydrophilic antioxidants in virgin olive oils (Olea Europea L.) and correlations with oxidative stability. Sci. Hortic-Amsterdam 112, 108-119. http://dx.doi. org/10.1016/j.scienta.2006.12.036.

Tura D, Failla O, Bassi D, Pedo S, Serraiocco A. 2009. Environmental and seasonal influence on virgin olive (Olea europaea L.) oil volatiles in northern Italy. Sci Hortic-Amsterdam 122 385-392. http://dx.doi.org/10.1016/j.scienta.2009.05.021

Valls RM, Farras M, Suarez M, Fernandez-Castillejo S, Fito M, Konstantinidou V, Fuentes F, Lopez-Miranda J, Giralt M, Covas MI, Motilva MJ, Sola R. 2015. Effects of functional olive oil enriched with its own phenolic compounds on endothelial function in hypertensive patients. A randomised controlled trial. Food Chem. 167, 30-35. http:// dx.doi.org/10.1016/j.foodchem.2014.06.107.

Vauzour D, Corona G, Spencer JPE. 2010. Caffeic acid, tyrosol and $p$-coumaric acid are potent inhibitors of 5-S-cysteinyldopamine induced neurotoxicity. Arch. Biochem. Biophys. 501, 106-111. http://dx.doi.org/10.1016/j.abb.2010.03.016.

Yoon SA, Kang SI, Shin HS, Kang SW, Kim JH, Ko HC, Kim SJ. 2013. $p$-Coumaric acid modulates glucose and lipid metabolism via AMP-activated protein kinase in L6 skeletal muscle cells. Biochem. Bioph. Res. Co. 432, 553-557. http://dx.doi.org/10.1016/j.bbrc.2013.02.067. 